\title{
Cycle pruning programmed on the grain yield of arabica coffee
}

\section{Poda programada de ciclo na produtividade do cafeeiro arábica}

\author{
Diego Corona Baitelle ${ }^{*}\left(\mathbb{D}\right.$, Abraão Carlos Verdin Filho² ${ }^{(\mathbb{D}}$, Sílvio de Jesus Freitas ${ }^{3}$ (D), \\ Guilherme Bessa Miranda ${ }^{3}$ (D) Henrique Duarte Vieira ${ }^{3}$ (D) Kezia Moraes Vieira ${ }^{3}$ (i)
}

\author{
1Universidade Estadual do Norte Fluminense Darcy Ribeiro/UENF, Laboratório de Fitotecnia/LFIT, Campos dos Goytacazes, RJ, Brasil \\ 2Instituto Capixaba de Pesquisa, Assistência Técnica e Extensão Rural/Incaper, Marilândia, ES, Brasil \\ 3Universidade Estadual do Norte Fluminense Darcy Ribeiro/UENF, Campos dos Goytacazes, RJ, Brasil \\ *Corresponding author: dg.corona@gmail.com \\ Received in June 13, 2019 and approved in December 12, 2019
}

\begin{abstract}
The cycle pruning programmed is a reinvigoration technique widely employed in Conilon coffee. This strategy may also be adopted for Arabica coffee to increase its crop longevity and yield. In this scenario, the present study proposes to examine the influence of the cycle pruning programmed on the vegetative and productive development of Arabica coffee. The experiment was developed in the field as a randomized-block design with four replicates. Treatments were tested in a $4 \times 2$ factorial arrangement consisting of four stem densities

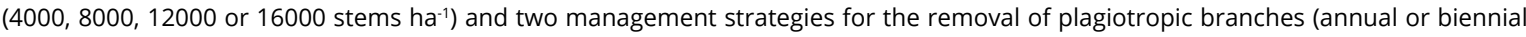
removal of branches which had reached $70 \%$ or more of their production capacity). For some variables, the treatments were organized as a $4 \times 2 \times 2$ factorial arrangement in which the last factor corresponded to two regions of data collection in the plant (upper or lower). For all factorial arrangements, an additional treatment (control) was employed corresponding to traditional pruning (recepa). Annual or biennial removal of plagiotropic branches which had attained $70 \%$ or more of their production capacity can be adopted with no losses to crop yield. The cycle pruning programmed improves the distribution of branches, increases canopy area and prevents the occurrence of the "naked neck" phenomenon, observed in control treatment. Additionally, it provides better agronomic and productive performance; therefore, it can be used as a substitute for recepa.
\end{abstract}

Index terms: Vegetative growth; stem density; plagiotropic branches; reinvigoration.

\begin{abstract}
RESUMO
A poda programada de ciclo é uma técnica de revigoramento muito empregada no cafeeiro conilon. É possível que ela possa ser adotada no cafeeiro arábica aumentando a longevidade e a produtividade das lavouras. Nesse contexto, objetivou-se avaliar a influência da poda programada de ciclo no desenvolvimento vegetativo e produtivo do cafeeiro arábica. 0 experimento foi conduzido a campo no delineamento em blocos casualizados com quatro repetições. Os tratamentos foram dispostos em esquema fatorial $4 \times 2$, sendo quatro densidades de hastes (4000, 8000, 12000 e 16000 hastes ha-1) e dois manejos para retirada de ramos plagiotrópicos (retirada anual e bienal de ramos que apresentaram $70 \%$ ou mais da sua produção). Para algumas variáveis, os tratamentos foram organizados em esquema fatorial $4 \times 2 \times 2$, sendo o último fator referente a duas posições de coleta de dados na planta (superior e inferior). Para todos os esquemas fatoriais foi empregado um tratamento adicional (testemunha), referente à poda tradicional (recepa). A retirada anual ou bienal de ramos plagiotrópicos que apresentaram $70 \%$ ou mais da sua produção pode ser empregada sem prejuízos à produtividade. A poda programada de ciclo melhora a distribuição de ramos, aumenta o tamanho da copa, e impede a ocorrência do fenômeno de "pescoço pelado", observado na testemunha. A poda programada de ciclo proporciona maior desempenho agronômico e produtivo, podendo ser utilizada em substituição à recepa.
\end{abstract}

Termos para indexação: Crescimento vegetativo; densidade de hastes; ramos plagiotrópicos; revigoramento.

\section{INTRODUCTION}

Decreased vigor and yield are known effects in Arabica coffee after a few production cycles. In this regard, the yield bienniality issue, characterized by annual alternation between high and low yields, is commonly attributed to a reduction of plant reserves during high- yielding harvest years that causes the yield in the following year to be low due to lower plagiotropic branch development. The annual variation may also occur as a result of defoliation caused by pests and diseases, since their incidence is favored by the energy depletion of the plant (Oliveira et al., 2012). In this situation, not even practices such as densification or irrigation are capable of 
changing this behavior (Pereira et al., 2011; Scalco et al., 2011). In this scenario, pruning emerges as an interesting reinvigoration technique aimed at restoring the plant's productive capacity (Fernandes et al., 2012).

The traditional pruning systems employed in Arabica coffee are esqueletamento, recepa and decote. Esqueletamento consists of trimming the plagiotropic branches at approximately $40 \mathrm{~cm}$ from the stem, whereas in recepa all plant stems are removed by a horizontal cut made approximately 40 to 60 above the soil. Lastly, decote is a type of pruning aimed at lowering plant height by cutting the stem apex, whose height ranges from 1.60 to $2.60 \mathrm{~m}$ from the soil (Japiassú et al., 2010; Pereira et al., 2013; Silva et al., 2016).

However, intense use of these pruning techniques may have drastic effects on plants, such as decreased yield in the year following the practice, leading to absent yield ("zero harvest"), and reduction in the root system, which in some cases may result in plant death due to the great removal of the vegetative part (Kumar et al., 2010; Gonçalves et al., 2014; Silva et al., 2016). Besides those problems, the use of traditional pruning in Arabica coffee culminates in disarray in the plant architecture, hindering cultivation practices such as harvesting as well as causing the "naked neck" effect. The "naked neck" is a phenomenon characterized by the death of plagiotropic branches with a high production capacity that is usually located in the middle third of the canopy of the plants. This is because the high density of fruit in this region leads to depletion of starch reserves and consequently, the weakening of the most productive plagiotropic branches (Amaral; DaMatta; Rena, 2001). The consequence of "naked neck" is increased leaf growth and branch density in the lower part of the plant and little leaf growth in the middle third.

At present, the most effective pruning system in Conilon coffee is the cycle pruning programmed (CPP), which consists of changing the plant architecture so as to maintain 12,000 to 15,000 orthotropic branches per hectare (Verdin-Filho et al., 2016) and eliminating the plagiotropic branches which have already attained $70 \%$ of their production capacity. The cycle pruning programmed has several advantages when compared to traditional systems, e.g., increased average yield and standardization of the crop; reduced total man labor in the long term, as CPP is performed at every four or five cycles; greater ease in thinning and cultivation practices; greater uniformity of flowering and fruit maturation; greater ease in pest and disease control; higher production stability per cycle; and non-occurrence of "zero harvest", ensuring yearly production (Gathaara; Kiara, 1984; Verdin-Filho et al., 2014; Verdin-Filho et al., 2016; Baitelle et al., 2018).

As occurs in Conilon coffee, programmed pruning in Arabica coffee (PPAC) may change the plant architecture, leading to the formation of multi-stemmed plants. Moreover, PPAC may reduce mortality in the plants subjected to pruning, increase their longevity and yield due to reinvigoration as well as reduce yield bienniality.

Baitelle et al. (2018) studied the use of PPAC and concluded that, in the long term, it is more economically viable than the recepa for mountain coffee growers who do not adopt mechanization. They concluded that at a minimum attractiveness rate of $12 \%$, the implementation of scheduled pruning is feasible as it generates a TRI of $15.30 \%$, about 3.3 percentage points higher than the minimum attractiveness rate. Coffee crop managed with traditional pruning using "recepa" becomes unfeasible, since this management generates an IRR of only $3.61 \%$. It can be observed from the Monte Carlo method that when using the cycle pruning programmed, the probability of NPV being negative, with $10 \%$ attractiveness, is null, ie, this pruning system, besides being economically viable, has a higher stability and security of investment for coffee farmers. In relation to traditional pruning, it is observed that there is a $30.5 \%$ probability of NPV being negative.

Because few studies have investigated PPAC, the stem density and management of plagiotropic branches that will provide better results have not yet been defined. The present study thus proposes to analyze the vegetative and productive aspects of Arabica coffee subjected to the cycle pruning programmed under different stem densities and management strategies for the removal of plagiotropic branches.

\section{MATERIAL AND METHODS}

The study was developed in the field, in the district of Alto Mutum Preto, located in the municipality of Baixo Guandú, northwestern region of Espírito Santo State, Brazil (19²1'44.32" S and 40'50'31.95" W, 634 $\mathrm{m}$ altitude). According to the Köppen classification, the area is located in a region with an Aw-type climate (humid tropical), where the average temperature is $21.4^{\circ} \mathrm{C}$, average annual precipitation is $1,260 \mathrm{~mm}$ (Climate-Data, 2019) and the relief is wavy-rough.

The experiment was set up as a randomizedblock design with four replicates. For the variables stem diameter (SD), plant height $(\mathrm{PH})$ and grain yield $(\mathrm{GY})$, the treatments were organized in a $4 \times 2$ factorial arrangement 
with an additional treatment, consisting of four stem densities (4000, 8000, 12000 and 16000 stems per hectare) and two management strategies for the removal of plagiotropic branches (annual or biennial removal of branches which had reached $70 \%$ or more of their total production capacity).

A $4 \times 2 \times 2$ triple factorial arrangement was used to study the other variables, namely, length of the plagiotropic branch in the lower third (LLB), length of the plagiotropic branch in the upper third (LUB), number of rosettes per lower plagiotropic branch (NRLB), number of rosettes per upper plagiotropic branch (NRUB), lower-canopy diameter (LCD) (skirt) and upper-canopy diameter (UCD). The factorial arrangement was represented by the combination of four stem densities, two management strategies for the removal of plagiotropic branches and two regions of data collection in the plant (at the skirt [fourth branch counted from the base to the apex, representing the lower third of the plant] or in the upper part [fourth branch counted from the apex to the base, representing the upper third of the plant]).

The additional treatment (control) was represented by the pruning traditionally performed on the crop, in which one stem predominates per plant and the plagiotropic branches are not removed. Later, the recepa is performed after the plants have lost plant vigor.

The experimental crop was formed by cultivar Catuaí Vermelho IAC 81, a late-maturing variety, at 12 years of age, which was cultivated with plants spaced $1.0 \mathrm{~m}$ apart and rows $2.5 \mathrm{~m}$ apart and trained in dryland conditions. Fertilizer applications and cultivation treatments were performed in accordance with the recommendations of Matiello et al. (2016).

In July 2013, after the fruits were harvested, the CPP was introduced in the crop by removing $75 \%$ of the old stems and plagiotropic branches which had reached $70 \%$ or more of their production capacity, in order to promote entry of light at the plant base and consequent production of vigorous shoots, following the management of the CPP used in Conilon coffee (Verdin-Filho et al., 2014). Thinning was first performed at 50 days after pruning to select the number of shoots respectively to the number of stems in each treatment. Additional shoots that emerged after selection were eliminated periodically.

After the fruits were harvested in 2014, the remaining stems from the 2013 pruning were removed and the crop remained only with the previously selected shoots. In 2015, the fruits from the stems formed after the CPP was implemented were harvested for the first time, which was followed by removal of plagiotropic branches which had reached $70 \%$ of their production capacity or more.

Vegetative growth and GY were evaluated in the 2015, 2016, 2017 and 2018 harvests. The following variables were determined in each evaluation of growth: SD, PH, LLB, LUB, NRLB, NRUB, LCD, UCD. Once the evaluations were finished, the data were subjected to statistical analysis.

Stem diameter was measured using a precision caliper, at the first internode on the stem located $10 \mathrm{~cm}$ above the soil. For the treatments with more than one stem, SD was expressed as the arithmetic mean of the measurements from all stems. Plant height was determined using a tape measure from the insertion of the longest stem on the trunk to the stem apex.

To determine LLB, the four lowest plagiotropic branches from the plant base were measured, whereas LUB was obtained by measuring the four uppermost plagiotropic branches from the stem apex to the plant base. The branches were measured in each of the four quadrants of the plant. The final value was expressed as the arithmetic mean of the four measurements.

To determine NRLB and NRR, the number of rosettes present in the lower and upper branches were counted, following the methodology established for LLB and LUB. The lower- and upper-canopy diameters were estimated from LLB and LUB, with LLB considered the radius of the circumference to estimate LCD (plant skirt diameter) and LUB considered the radius of the circumference to estimate UCD. The average stem diameter, in turn, was estimated from the simple arithmetic mean of the LCD and UCD data.

To determine GY, the fruits were harvested using a sieve when green fruits corresponded to less than $20 \%$. All plants were harvested from the plot, and the produce of each plot was identified and dried individually in an overhead oven. Fruits were processed when the water content in the grains was near $12 \%$ (wet basis). After weighing the grains, the result was extrapolated to bags of processed grain per hectare.

The mean data were subjected to normality and homoscedasticity analyses followed by analysis of variance (ANOVA). For the factors removal of plagiotropic branches and collection region, the means of those treatments were compared by Tukey's test $(\mathrm{P} \leq 0.05)$. For the effects of the stem density factor, the variables were studied by regression analysis $(\mathrm{F} \leq 0.05)$. The additional treatment (control) was compared by decomposing the sum of squares of treatments into orthogonal contrasts, establishing and testing the contrast between control and 
BAITELLE, D. C. et al.

the other treatments $(\mathrm{F} \leq 0.05)$. Statistical analyses were performed using Sisvar statistical software version 5.6 (Ferreira, 2011).

\section{RESULTS AND DISCUSSION}

Analysis of variance revealed that, for the double factorial treatment, there was a difference in the orthogonal contrast between the means of the factorial (conducted as PPAC) and control treatments. The orthogonal contrasts showed that the factorial treatment was superior to control for GY and $\mathrm{PH}$ but inferior for $\mathrm{SD}$, as described in Table 1.

The fact that control treatment yielded less than the other treatments in all evaluated harvests may be related to loss of vigor and occurrence of "naked neck" in the plants. In the CPP treatments, however, there was homogeneous distribution of leaves and fruit production along the plant. These results corroborate those presented by Verdin-Filho et al. (2016), who also observed an increase in yield with PPAC and concluded that the higher number of stems per area increased the yield of Arabica coffee.

Assis et al. (2014) stated that there is a direct correlation between the number of plagiotropic branches and yield in Arabic coffee, which the present results confirm. In the current study, one of the reasons why the yield of Arabica coffee trained under CPP was higher than that of control treatment was the higher number and better distribution of plagiotropic branches on the plants.

The uniform distribution of branches and leaves in the CPP treatments is a consequence of the removal of plagiotropic branches which had already achieved more than $70 \%$ of their production capacity, from the skirt. The plagiotropic branches located at the skirt of control plants may act as a drain due to the low light compensation point. Because they are in the lower portion of plants, this area receives fewer hours of photosynthetically active light, causing those branches to produce few photoassimilates in relation to the middle and upper branches on the plant. This fact could be minimized by adopting larger spacing in planting.

Furthermore, the lower branches of the plants in control treatments may act as a drain to the nutrients exported by the roots, preventing vigorous development of the other branches located in the upper parts.

In the opinion of Silva et al. (2011), one of the main factors defining the draining power of plants is the proximity of the drains to the source. Sources typically translocate nutrients to the drains nearest to them. This assertion is corroborated by the present findings, in which control treatment showed a larger average SD, measured at the plant skirt, indicating that there this region has reserve tissue that provides greater leaf production.

The greater PH observed in PPAC may be related to self-competition for light caused by the higher stem densities. Similar results were obtained by Pereira et al. (2011), who reported that densification influenced the growth and architecture of coffee plants, resulting in taller plants in the denser management systems. According to Pereira et al. (2011), in dense coffee plantings, there is greater plant growth, which leads to greater self-shading and consequent death of the lower plagiotropic branches due to deficient radiation on that part of the plant. Conversely, the lower height of the plants cultivated in rows spaced further apart was offset by longer and lower plagiotropic branches, as was observed in the current study.

In the comparison between the PPAC treatments, ANOVA revealed that a difference only occurred in the isolated factor stem density in all variables analyzed for the double factorial treatment. For GY, the regression indicated a quadratic trend in all evaluated crop years, with the highest yields achieved at the estimated average density of 12,531 stems ha-1 (Figure 1). Even at the lowest stem densities $\left(4,000\right.$ stems $\left.^{-1} \mathrm{a}^{-1}\right)$, the means obtained under the CPP were higher than those observed in control.

Table 1: Mean values of orthogonal contrasts between the factorial and control treatments for grain yield in the harvests of 2015 to 2018, stem diameter (SD) and plant height (PH) of Coffea arabica L. 'Catuaí Vermelho IAC 81' trained under the cycle pruning programmed in Alto Mutum - ES, Brazil.

\begin{tabular}{cccccccc}
\hline & \multicolumn{9}{c}{ Grain yield (bags ha-1) } & \multicolumn{2}{c}{ Growth } \\
\hline Treatment & 2015 & 2016 & 2017 & 2018 & Average & SD $(\mathrm{mm})$ & $\mathrm{PH}(\mathrm{cm})$ \\
Factorial (PPAC) & $38.29 \mathrm{a}$ & $41.13 \mathrm{a}$ & $17.00 \mathrm{a}$ & $52.90 \mathrm{a}$ & $37.33 \mathrm{a}$ & $32.12 \mathrm{~b}$ & $166.16 \mathrm{a}$ \\
Control & $23.57 \mathrm{~b}$ & $31.99 \mathrm{~b}$ & $9.81 \mathrm{~b}$ & $36.75 \mathrm{~b}$ & $25.53 \mathrm{~b}$ & $40.59 \mathrm{a}$ & $149.21 \mathrm{~b}$ \\
CV (\%) & 18.34 & 22.80 & 32.45 & 18.09 & 13.85 & 4.53 & 3.96 \\
\hline
\end{tabular}

Means followed by the same letter in the column do not differ from each other according to the $\mathrm{F}$ test at the $5 \%$ probability level. 


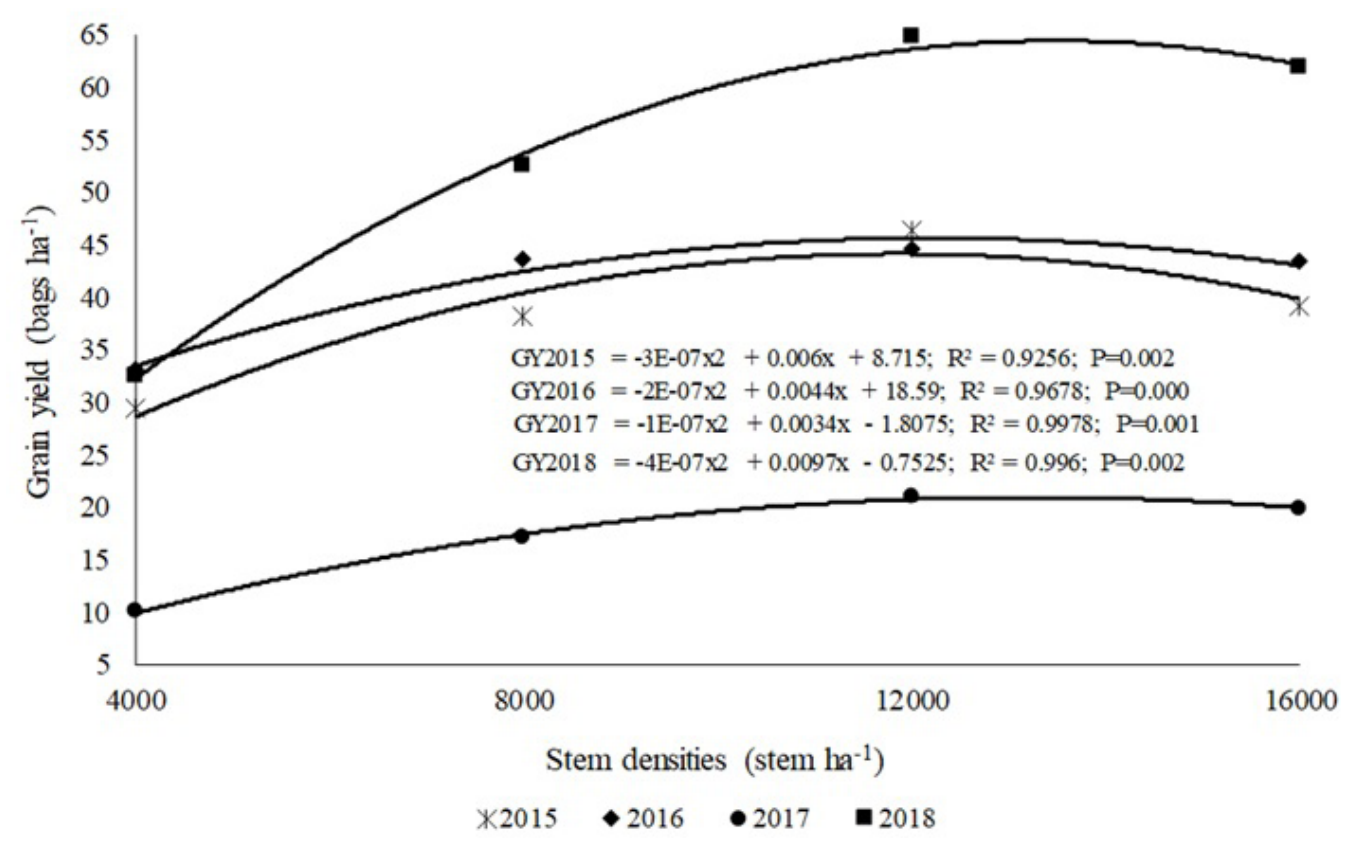

Figure 1: Grain yield (bags ha-1) of Coffea arabica L. 'Catuaí Vermelho IAC 81 ' trained under the cycle pruning programmed at different stem densities, in the 2015, 2016, 2017 and 2018 harvests, in the region of Alto Mutum - ES, Brazil.

It is clear that the CPP associated with the stem densities changed the crop yield between the years 2015 and 2018. Yield showed an upward trend as the number of stems was elevated, with the highest values achieved near the density of 12,531 stems ha $^{-1}$. After that density, yield started to decline. In all CPP treatments, the density of 4,000 stems ha ${ }^{-1}$ provided the lowest yield. This result is directly related to the lower number of productive stems per area.

The yield data obtained in this study corroborate those reported by Verdin-Filho et al. (2014), who studied the yield of Conilon coffee using the CPP at different stem densities. Those authors found that a higher number of stems per plant tends to increase GY, whereas lower stem densities resulted in lower yields.

There was a sudden drop in GY in 2017 compared to the other years. This fact may be explained by the great water deficient occurring in the state of Espírito Santo in the second half of 2015 and in the year 2016. Because the studied crop is cultivated in dryland conditions, the lack of water during that period contributed to the decreased yield in all treatments in the 2017 harvest, as shown in Table 2.

Adverse climatic conditions may limit fruit production in coffee plants, especially due to the occurrence of droughts and unfavorable temperatures.
Scalco et al. (2011) investigated irrigated and nonirrigated cultivation of coffee (Coffea arabica L.) under super-dense planting and observed that the use of irrigation increased the average yield by $44 \%$ throughout seven harvests in relation to the non-irrigated system. Fernandes et al. (2016) evaluated the technical and economic viability of localized irrigation in Arabica coffee in the climatic conditions of Planalto de Araxá MG, Brazil, and found that the non-irrigated treatment led to a $38 \%$ lower yield per year compared to the irrigated treatment.

The greater stem density in the CPP treatments contributed to increasing yield. Valadares et al. (2013) reported that denser crops better utilize solar radiation and nutrient cycling by virtue of the larger leaf surface and root density, which culminate in increased production.

One of the great advantages of densification is increased yield, especially in the first harvests. However, it may also lead to increased competition among plants for light, water and nutrients as they grow (Pereira et al., 2013; Andrade et al., 2014). We believe competition might have occurred at the stem densities higher than 12,531 stems ha $^{-1}$ - for light, mainly -, which resulted in a decreased photosynthetic rate and, consequently, reduced yield. 
Table 2: Average annual precipitation in the period of 2013 to 2018 in the district of Alto Mudum, Baixo Guandu - ES, Brazil.

\begin{tabular}{ccccccc}
\hline $\begin{array}{c}\text { Period } \\
\text { (Years) }\end{array}$ & 2013 & 2014 & 2015 & 2016 & 2017 & 2018 \\
\hline $\begin{array}{c}\text { Precipitation } \\
(\mathrm{mm})\end{array}$ & 1670 & 1309 & 608 & 728 & 1193 & 1584 \\
\hline
\end{tabular}

Another factor that might have contributed to the lower yield found at the density of 16,000 stems ha $^{-1}$ is premature death of plagiotropic branches in the upper third of the coffee plants due to shading. Reducing the space between stems intensifies the death of plagiotropic branches in the lower third of coffee plants, leading to a progressive loss of yield (Scalco et al., 2011) and preventing the maintenance of this number of stems in the CPP.

In a comparison between the PPAC treatments, $\mathrm{PH}$ showed a positive quadratic response in the regression, with plants tending to grow taller as stem density was elevated. The opposite was true for SD, which showed a negative quadratic response, as depicted in Figure 2.

According to Pereira et al. (2013), the competition for light among plants caused by the higher stem density over the years alters the distribution and uptake of dry matter, favoring vertical growth in the orthotropic branch over secondary stem growth. This contributed to the reduction in $\mathrm{SD}$ with a simultaneous increase in $\mathrm{PH}$ as stem density was elevated, as observed in this study. Pereira et al. (2011) observed that reducing the space between plants in the planting row reduced SD, which also occurred at the higher stem densities in the current experiment.

Confirming the assertions made by Pereira et al. (2011), the "naked neck" phenomenon was observed in the field only in the free-growing control plants. This phenomenon leads to weakening of the most productive plant parts (middle third) due to the great fruit load, which depletes the starch reserves in those regions (Amaral; DaMatta; Rena, 2001). "Naked neck" then increases yield bienniality, since the productive area of the middle third of the plant is compromised by the death of plagiotropic branches.

The greater leaf production occurring at the skirt of the control plants is thought to result in a higher concentration of internal products and photoassimilates in the lower part of the plant and, consequently, a lower concentration thereof in the upper part. This fact results in a reduction of primary growth and contributes to the lower height observed in control treatment.
When the CPP is introduced in Arabica coffee, the lower plagiotropic branches must be removed. Thus, the skirt is removed and no plants with "naked neck" are formed. In this way, it is believed that all the nutrients absorbed by the plants are better distributed, which contributes to homogeneous growth without leaf production or concentration of product in the lower part of plants.

For the triple factorial treatment, which considered data collection from the lower and upper regions of the plants, stem densities and removal of plagiotropic branches, ANOVA revealed a difference in the orthogonal contrast between the means of the factorial and control treatments in the two collection regions. The means for plagiotropic branch length (PBL) and canopy diameter (CD) from the lower part of the plants in control treatment were higher than those found in the upper part of control plants and higher than the means found in the factorial treatment. Number of rosettes per plagiotropic branch (NRPB) showed a higher mean in the lower collection region in control plants, and there was no difference between the factorial and control treatments for the material collected from the upper part (Table 3).

In the lower region of data collection at the plant (skirt), the results obtained by control treatment were higher than those found in PPAC. However, the results for the same variables in the upper part (canopy) were opposite, with control generating the worst outcomes for PBL and CD. For the NRPB variable, there was no difference between the evaluations made in the canopy of plants in the control or factorial treatments. This fact evidences the presence of "naked neck" in the control plants, which have a greater concentration of branches and leaves in the lower part (skirt).

In control, the "naked neck" phenomenon observed in the field associated with the lower stem density might have led to greater growth of the skirt part of the plants when compared to the CPP treatments. This large difference in branch size may be explained by the higher number of branches at the skirt of the coffee plant that act as a nutrient drain by being near the root system (Silva et al., 2011), thereby reducing homogeneous distribution along the plant and preventing normal canopy growth.

According to Fonseca et al. (2017), as the orthotropic branches age, their productive capacity decreases due to the reduction of vigor, whereas the number of shoots increases. Therefore, for the purpose of commercial exploitation of the crop, it is necessary to intervene in the free growth of the plants as well as substitute old orthotropic and plagiotropic branches by new ones. 

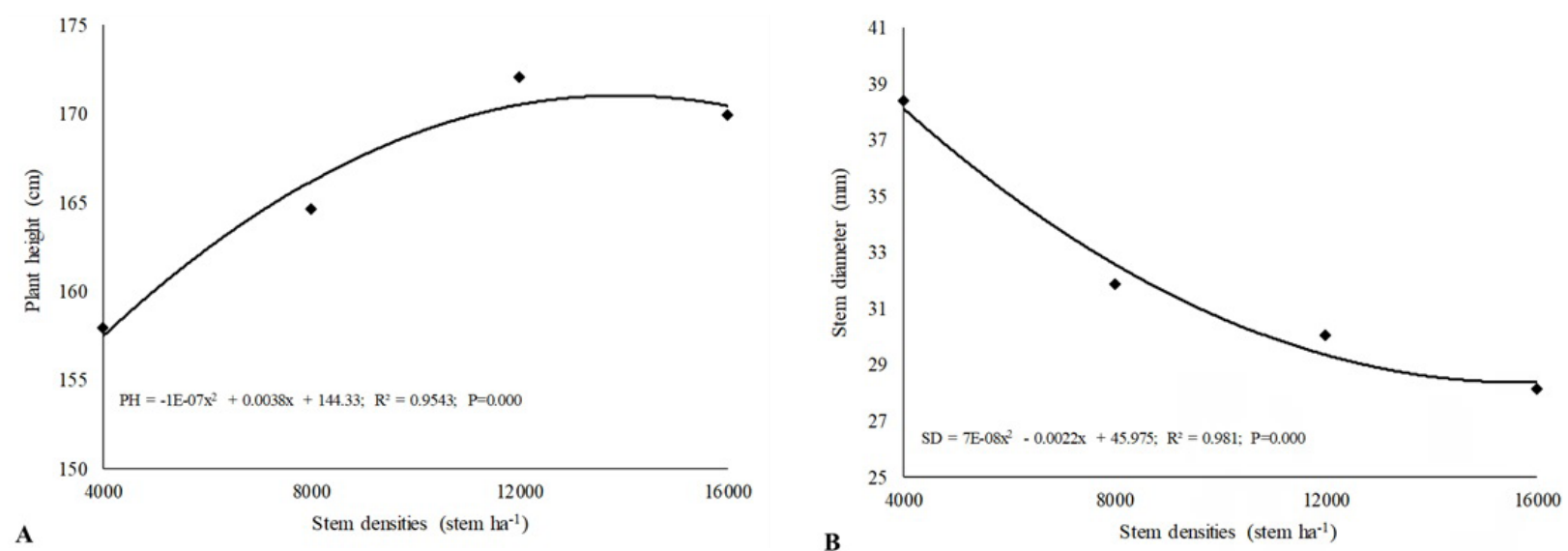

Figure 2: Plant height (A) and stem diameter (B) in Coffea arabica L. 'Catuaí Vermelho IAC 81 ' trained under the cycle pruning programmed at different stem densities in the region of Alto Mutum - ES, Brazil.

Table 3: Mean values of orthogonal contrasts between the factorial and control treatments in the lower and upper collection regions for number of rosettes on the plagiotropic branch (NRPB), plagiotropic branch length (PBL) and canopy diameter (CD) of Coffea arabica L. 'Catuaí Vermelho IAC 81' trained under the cycle pruning programmed in Alto Mutum - ES, Brazil.

\begin{tabular}{cccc}
\hline Treatment & NRPB & PBL & \multicolumn{1}{c}{ CD } \\
\hline Factorial (PPAC) & $8.94 \mathrm{~b}$ & $47.53 \mathrm{~b}$ & $96.32 \mathrm{~b}$ \\
Control - upper part & $6.78 \mathrm{~b}$ & $18.14 \mathrm{c}$ & $36.28 \mathrm{c}$ \\
Control - lower part & $11.95 \mathrm{a}$ & $82.84 \mathrm{a}$ & $165.69 \mathrm{a}$ \\
\hline $\mathrm{CV}(\%)$ & 11.59 & 5.62 & 6.52
\end{tabular}

Means followed by the same letter in the column do not differ from each other according to Tukey's test at the 5\% probability level.

In comparing the factorial treatments, ANOVA revealed a double interaction between the factors collection region and removal of plagiotropic branches for the PBL and CD variables. For NRPB, a significant double interaction was detected between stem density and removal of plagiotropic branches.

Table 4 reveals the decomposition of the significant double interaction between collection region and removal of plagiotropic branches. Plagiotropic branch length and CD behaved similarly, with higher values observed when the branches were removed annually, in the lower collection region (skirt). Under both annual and biennial removal of plagiotropic branches, the lower part of the plants (fourth branch counted from the base) had longer plagiotropic branches in relation to the canopy, which resulted in a larger diameter in the lower third of those plants.
Table 4: Double interaction between the factors removal of plagiotropic branches and collection region for plagiotropic branch length and canopy diameter in Coffea arabica L. 'Catuaí Vermelho IAC 81' trained under the cycle pruning programmed in Alto Mutum - ES, Brazil.

\begin{tabular}{ccccc}
\hline & \multicolumn{2}{c}{$\begin{array}{c}\text { Plagiotropic branch } \\
\text { length (cm) }\end{array}$} & \multicolumn{2}{c}{$\begin{array}{c}\text { Canopy diameter } \\
\text { (cm) }\end{array}$} \\
\hline $\begin{array}{c}\text { Collection } \\
\text { region }\end{array}$ & \multicolumn{2}{c}{ Branch removal } & \multicolumn{2}{c}{ Branch removal } \\
\cline { 2 - 5 } & Annual & Biennial & Annual & Biennial \\
\hline Upper & $21.20 \mathrm{aB}$ & $21.65 \mathrm{aB}$ & $42.39 \mathrm{aB}$ & $43.31 \mathrm{aB}$ \\
Lower & $82.17 \mathrm{aA}$ & $67.61 \mathrm{bA}$ & $164.35 \mathrm{aA}$ & $135.22 \mathrm{bA}$ \\
\hline $\mathrm{CV}(\%)$ & \multicolumn{2}{c}{5.62} & 6.52
\end{tabular}

Means followed by the same uppercase letter in the row and lowercase letter in the column do not differ from each other according to Tukey's test at the 5\% probability level.

The direct capture of light in the upper part of the plants at the different stem densities in PPAC prevented a reduction in the growth of upper plagiotropic branches due to densification. As a result, no difference was observed between the densities for that variable.

Annual removal was found to favor the growth of the plagiotropic branches that remained in the upper portion of the plants compared to the strategy of biennial removal. This can be explained by the greater incidence of light on the plants, which favors the production and growth of lateral shoots.

In the treatments of annual and biennial removal, the elimination of plagiotropic branches in the lower third of the plants provides a new canopy architecture, benefiting the development of the upper plant, which explains why PPAC led to better results for this variable 
than control. Thus, the removal of plagiotropic branches in the cycle pruning programmed allows for a larger canopy diameter and, consequently, longer plagiotropic branches in the upper third of plants when compared to control (Table 3 ).

The presence of longer plagiotropic branches in the lower region is due to their age, considering that chronologically older branches are consequently lower. Furthermore, it is believed that the self-shading caused at the plant skirt prompts increased growth of the branches and leaves in that region, in an effort to seek luminosity (Pereira et al., 2011).

Figure 3 displays the decomposition of the significant double interaction between data collection region and stem density for number of rosettes per plagiotropic branch. The regression was significant only for the lower position, where a negative effect was observed; i.e., the number of rosettes at the plant skirt tends to decrease as stem density is elevated, in PPAC.

The lower number of rosettes per branches observed at the higher densities is caused by self-shading.
Self-shading leads to internode elongation, which reduces the number of rosettes along the plagiotropic branch. Consequently, there is a downward trend in yield at densities greater than 12,531 stems $\mathrm{ha}^{-1}$, because the number of rosettes is directly related to fruit production. Colodetti et al. (2018) also observed a decrease in number of nodes and number of rosettes in the treatments with higher stem densities in Arabica coffee. According to those authors, one of the factors that contributed to this occurrence might have been low entry of light into the more densified areas.

Cycle pruning programmed is best suited for family farmers who do not adopt mechanized harvesting. The recommendation is that the producer establish the spacing to be adopted in the crop according to the variety to be cultivated, climate of the region and slope of the land. Then establish the density of 12,000 stems ha- 1 and clean the plagiotropic branches that have reached $70 \%$ or more of productive capacity every two years.

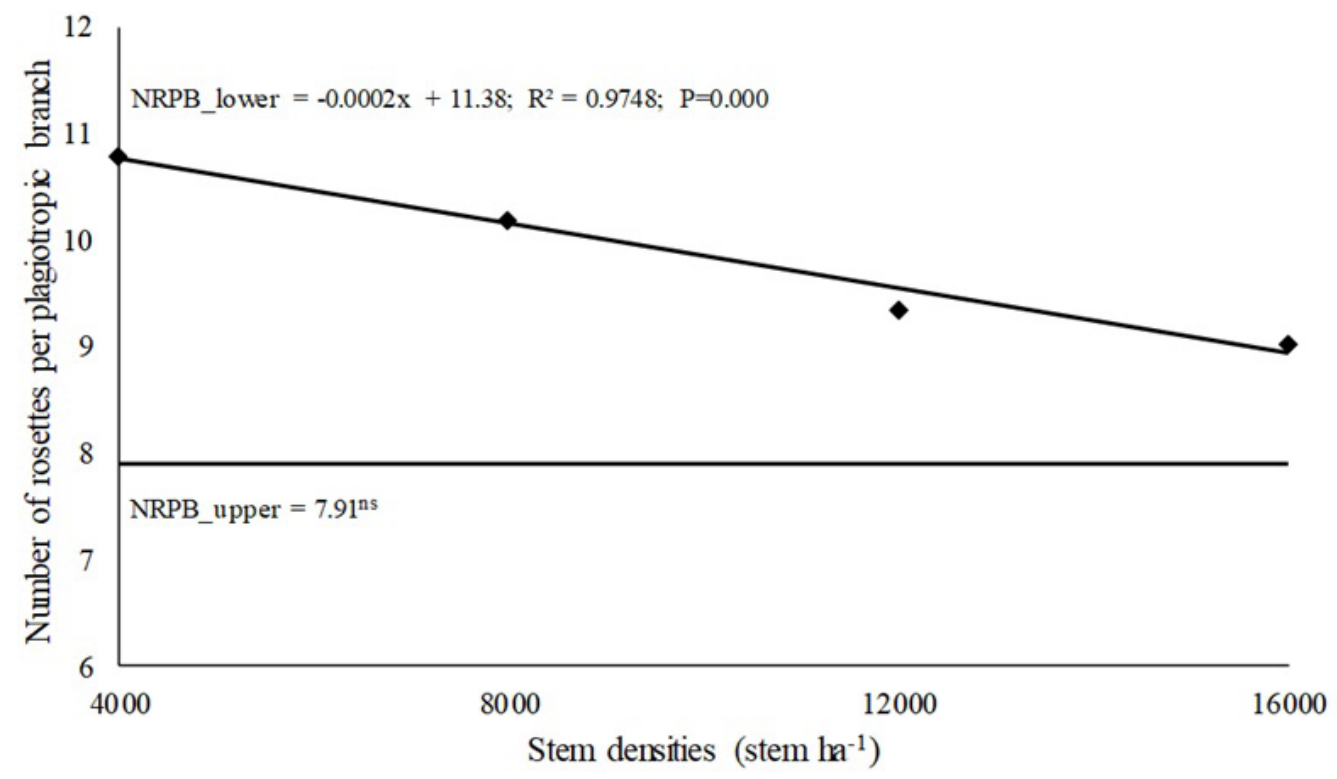

Figure 3: Number of rosettes per plagiotropic branch (NRPB) evaluated in the lower (skirt) and upper (canopy) regions of Coffea arabica L. 'Catuaí Vermelho IAC 81' plants under the cycle pruning programmed in Alto Mutum - ES, Brazil. 


\section{CONCLUSIONS}

Yield was higher in all treatments under the cycle pruning programmed compared to traditional pruning. In Arabica coffee cv. Catuaí IAC 81 under the cycle pruning programmed, plagiotropic branches that have reached $70 \%$ of their production capacity or more can be removed annually or biennially without losses to yield. Under the cycle pruning programmed, Arabica coffee cv. Catuaí IAC 81 grown with plants spaced $1 \mathrm{~m}$ apart in rows spaced $2.5 \mathrm{~m}$ apart, the estimated stem density that provides the highest yield is approximately 12,531 stems ha- ${ }^{-1}$. In Arabica coffee, the cycle pruning programmed improves the distribution of branches, increases plant height and canopy diameter and prevents the occurrence of the "naked neck" phenomenon, observed in control treatment. Under the cycle pruning programmed, stem diameter reduces as stem density is elevated.

\section{ACKNOWLEDGMENTS}

The authors thank CNPq for the Master's fellowship; Incaper for providing the infrastructure and laboratory materials; the rural producer Ademar Franskoviaky for allowing use of the production area for the experiment; and the Graduate Program in Plant Production at the State University of Northern Rio de Janeiro for all support provided.

\section{REFERENCES}

AMARAL, J. A. T.; DAMATTA, F. M.; RENA, A. B. Effects of fruiting on the growth of arabica coffee trees as related to carbohydrate and nitrogen status and to nitrate reductase activity. Revista Brasileira de Fisiologia Vegetal, 13(1):6674, 2001.

ANDRADE, W. E. B. et al. Produtividade do cafeeiro arábica em condições de adensamento, no noroeste Fluminense. Coffee Science, 9(1):90-101, 2014.

ASSIS, G. A. et al. Correlação entre crescimento e produtividade do cafeeiro em função do regime hídrico e densidade de plantio. Bioscience Journal, 30(3):666-676, 2014.

BAITELLE, D. C. et al. Feasibility and economic risk of programmed pruning cycle in arabic coffee. Journal of Experimental Agriculture International, 21(4):1-9, 2018.

CLIMATE-DATA. Dados climáticos para cidades mundiais. 2019. Available in: < https://pt.climate-data.org/ location/315832/>. Access in: April 02, 2019.
COLODETTI, T. V. et al. Arquitetura da copa do cafeeiro arábica conduzido com diferentes números de ramos ortotrópicos. Revista Ceres, 65(5):415-423, 2018.

FERNANDES, A. L. T. et al. Condução das podas do cafeeiro irrigado por gotejamento cultivado no cerrado de Minas Gerais. Enciclopédia Biosfera, 8(15):487-494, 2012.

FERNANDES, A. L. T. et al. Viabilidade técnica e econômica da irrigação localizada do cafeeiro, nas condições climáticas do Planalto de Araxá, MG. Coffee Science, 11(3):347-358, 2016.

FERREIRA, D. F. Sisvar: a computer statistical analysis system. Ciência e Agrotecnologia, 35(6):1039-1042, 2011.

FONSECA, A. F. A. et al. Manejo da cultura do café conilon: Plantio, espaçamento, podas e desbrotas. In: FERRÃO, R. G. et al. Café conilon. 2 ed. - Vitória, ES: Incaper, 2017, v. 1, p. 275-301.

GATHAARA, M. P. H.; KIARA, J. M. Factors that influence yield in close-spaced coffee. 1. Ligth, dry matter production and plant water status. Kenya Coffee. 49(580):203-211. 1984.

GONÇALVES, M. A. et al. Efeito da intensidade de poda na produção e qualidade de frutos de pessegueiro. Revista Brasileira de Fruticultura, 36(3):742-747, 2014.

JAPIASSÚ, L. B. et al. Ciclos de poda e adubação nitrogenada em lavouras cafeeiras conduzidas no sistema "safra zero". Coffee Science, 5(1):28-37, 2010.

KUMAR, M. et al. Effect of pruning intensity on peach yield and fruit quality. Scientia Horticulturae, 125(3):218-221, 2010.

MATIELLO, J. B. et al. Cultura de café no Brasil: manual de recomendações. Rio de Janeiro RJ/Varginha-MG: MAPA/ PROCAFE, v.1, 2016. 585p.

OLIVEIRA, I. P. et al. Cultivo de café: pragas, doenças, correção do solo, adubação e consórcio. Revista Eletrônica Faculdade Montes Belos, 5(4):56-77, 2012.

PEREIRA, S. P. et al. Crescimento, produtividade e bienalidade do cafeeiro em função do espaçamento de cultivo. Pesquisa Agropecuária Brasileira, 46(2):152160, 2011.

PEREIRA, S. P. et al. Influência do espaçamento de cultivo em duas épocas de poda nos teores caulinares de carboidratos em cafeeiros. Coffee Science, 8(4):460-468, 2013.

SCALCO, M. S. et al. Cultivo irrigado e não irrigado do cafeeiro (Coffea arabica L.) em plantio superadensado. Coffee Science, 6(3):193-202, 2011. 
SILVA, A. C. et al. Alocação de fotoassimilados marcados e relação fonte-dreno em figueiras cv. Roxo de Valinhos. 1. Relação fonte e dreno. Revista Brasileira de Ciências Agrárias, 6(3):409-418, 2011.

SILVA, V. A. et al. Recuperação de cultivares de café submetidas ao esqueletamento aos quatro anos e meio de idade. Coffee Science, 11(1):55-64, 2016.

VALADARES, S. V. et al. Produtividade e bienalidade da produção de cafezais adensados, sob diferentes doses de N e K. Pesquisa Agropecuária Brasileira, 48(3):296303, 2013.

VERDIN-FILHO, A. C. et al. Conilon coffee yield using the programmed pruning cycle and different cultivation densities. Coffee Science, 9(4):489494, 2014.

VERDIN-FILHO, A. C. et al. New management technology for arabica coffee: the cyclic pruning program for arabica coffee. Coffee Science, 11(4):475-483, 2016. 